\title{
PEMBINAAN KARAKTER DISIPLIN BERKENDARA MELALUI PEMBELAJARAN PENDIDIKAN KEWARGANEGARAAN DAN BUDAYA DISIPLIN
}

\author{
Weka Indriani dan Danang Prasetyo \\ Universitas Negeri Yogyakarta \\ Email: wekaindriany@gmail.com
}

\begin{abstract}
Abstrak: Penelitian ini bertujuan untuk mengungkap pembinaan karakter melalui pembelajaran Pendidikan Kewarganegaraan dan budaya disiplin. Penelitian ini merupakan penelitian deskriptif dengan pendekatan kualitataif. Penelitian dilakukan di SMP Negeri 9 Yogyakarta dengan subjek penelitian guru PKn dan Kepala Sekolah. Pengumpulan data dengan teknik wawancara, observasi, dan dokumentasi. Pemeriksaan keabsahan data dilakukan dengan triangulasi sumber. Analisis data dilakukan secara kualitatif model Miles \& Huberman melalui tahap pengumpulan data, reduksi data, penyajian data, dan penarikan kesimpulan. Hasil penelitian menunjukkan bahwa di SMP Negeri 9 Yogyakarta secara eksplisit melakukan pendidikan karakter disiplin berkendara melalui pembelajaran PKn dengan cara mengintegrasikan pendidikan disiplin berkendara pada pembelajaran norma hukum. Selain itu, di SMP Negeri 9 Yogyakarta secara eksplisit dilakukan melakukan pendidikan karakter disiplin berkendara melalui pembiasaan dengan cara menerapkan budaya disiplin berkendara di sekolah.
\end{abstract}

Kata Kunci: pembinaan karakter, disiplin berkendara, pembelajaran pendidikan kewarganegaraan, budaya disiplin

\section{CHARACTER BUILDING OF DRIVING DISCIPLINE THROUGH LEARNING OF CIVIC EDUCATION AND DISCIPLINE CULTURE}

\begin{abstract}
This research aims to uncover character building through learning od Civic Education and discipline culture. This research is a descriptive one with a qualitative approach. This research was conducted at State Junio High School 9 Yogyakarta with research subjects was the teacher of Civic Education and headmaster. The data were collected through interview, observation, and documentation techniques. Checking the validity of the data was done by triangulating the source. Data analysis was performed qualitatively by the Miles \& Huberman model through the stages of data collection, data reduction, data presentation, and drawing conclusions. The results showed that in State Junior High School 9 Yogyakarta explicitly conducted character education in driving discipline through Civics Education by integrating driving discipline education in learning legal norms. In addition, in State Junior High School 9 Yogyakarta explicitly conducted character education in driving discipline through habituation by applying the culture of driving discipline at school.
\end{abstract}

Keywords: character building, driving discipline, learning of civic education, discipline culture

\section{PENDAHULUAN}

Permasalahan lalu lintas di dunia masih menjadi masalah yang cukup serius, mengingat angka kecelakaan dan pelanggaran lalu lintas yang terjadi masih cukup tinggi. Merujuk data World Health Organization (WHO), tingginya angka kematian akibat kecelakaan sudah semakin kritis. Pada 2015, sekitar 1,25 juta orang meninggal per tahun, dengan rincian satu orang meninggal setiap 25 detik di seluruh dunia, hal ini diklaim akan semakin meningkat setiap harinya. Angka korban kecelakaan lalu lintas tersebut juga dinilai lebih tinggi dari angka korban HIV atau pembunuhan (Ravel, 2017a).

Tren kecelakaan lalu lintas di Indonesia setiap tahun terus mengalami peningkatan. Sepanjang 2014 tercatat 95.906 kasus, tahun selanjutnya 98.970 kasus, dan 
terakhir 2016 meningkat menjadi 105.374 kasus dengan korban meninggal dunia tercatat 25.859 orang, luka berat 22.939 orang, luka ringan 120.913 orang (Rostanti, 2017). Korban kecelakaan lalu lintas di Indonesia lebih banyakjika dibandingkan dengan jumlah korban terorisme, bencana sunami, dan bencana banjir. Bahkan, kecelakaan lalu lintas di Indonesia termasuk tinggi, (menduduki) ranking dua sampai tiga di bawah dalam lingkup ASEAN (Dewi, 2017).

Fenomena kecelakaan lalu lintas di Indonesia khususnya dinilai sangat mengkhawatirkan. Wakil Kepala Korps Polisi Lalu Lintas Mabes Polri Brigjen Pol Indrajit mengatakan bahwa faktor utama kecelakaan lalu lintas bermula dari pelanggaran lalu lintas (Ravel, 2017b). Bahkan, kejadian kecelakaan lalu lintas yang bermula dari pelanggaran lalu lintas banyak melibatkan pelajar terutama tingkat SMP (Purnama, 2017). Selanjutnya, Wakil Kapolri Komjen Pol Syarifudin mengatakan bahwa penyebab tingkat kecelakaan lalu lintas yang tinggi karena kurangnya kesadaran masyarakat untuk disiplin berkendara (Movanita, 2017).

Kesadaran disiplin berkendara juga berkaitan dengan kesadaran hukum masyarakat. Ali (2007:66-68) menyatakan bahwa kesadaran hukum masyarakat tinggi jika masyarakat menaati hukum karena hukum tersebut seharusnya sesuai dengan nilai-nilai yang dianut dalam kehidupan bermasyarakat. Jika melihat banyaknya fenomena pelanggaran lalu lintas yang dilakukan siswa dapat disimpulkan bahwa kesadaran disiplin berkendara siswa masih rendah.

Kuncorowati (2009: 65) menjelaskan bahwa rendahnya kesadaran hukum dapat ditingkatkan secara efektif dan efisien melalui pendidikan, baik pendidikan formal maupun pendidikan nonformal. Kesadaran hukum juga berkaitan dengan kesadaran disiplin berkendara, hal ini dikarenakan peraturan disiplin berkendara juga diatur dalam peraturan hukum. Berpedoman dari pendapat di atas, dapat disimpulkan bahwa pendidikan formal (sekolah) mempunyai peran yang penting dalam membina kesadaran disiplin berkendara siswa, sebagaimana Durkin (1999:1) mengemukakan bahwa pendidikan disiplin berkendara di sekolah efektif untuk mencegah kecelakaan dan pelanggaran lalu lintas yang dilakukan oleh siswa.

Di Indonesia, pendidikan disiplin berkendara diintegrasikan pada mata pelajaran Pendidikan Kewarganegaraan atau PKn. PKn mengemban misi di antaranya membina siswa agar mempunyai kesadaran hukum yang tinggi. Sebagaimana Maftuh \& Sapriya (2005:321) menjelaskan bahwa PKn sebagai pendidikan hukum mempunyai salah satu misi yaitu membina siswa menjadi warga negara yang memiliki kesadaran hukum yang tinggi. Maka dari itu, dapat disimpulkan bahwa untuk membina kesadaran disiplin berkendara pada siswa dapat diupayakan melalui pembelajaran PKn di sekolah. Dengan pembelajaran PKn guru dapat melakukan berbagai upaya melalui materi-materi yang diberikan serta metodemetode yang dipilih untuk menanamkan kesadaraan disiplin berkendara, sehingga siswa memahami, menyadari, dan mempraktikkannya dalam kehidupannya.

Kenyataannya pembelajaran PKn seringkali tidak mengarah pada misi sebagaimana mestinya, sehingga misi PKn dalam membina siswa agar memiliki kesadaran disiplin berkendara sampai saat ini belum terwujud sepenuhnya. Sunarso, dkk (2008: 2) menjelaskan bahwa salah satu alasan pembelajaran PKn belum mampu mewujudkan misi sebagaimana mestinya yaitu karena kurangnya keseimbangan antara pengeta- 
huan dan keterampilan dengan praktik pembiasaan perilaku dalam berkehidupan yang sadar hukum. Berpedoman dari pendapat di atas, dapat disimpulkan bahwa dalam membina karakter disiplin berkendara pada siswa dapat diupayakan dengan menyeimbangkan antara pemberian aspek pengetahuan dan keterampilan dengan praktik pembiasaan perilaku di sekolah.

Persoalan lain yang muncul yaitu bagaimana membina karakter disiplin berkendara pada siswa sehingga karakter tidak berhenti sebagai pengetahuan saja, tetapi mampu menjadi watak atau kebiasaan. Jika karakter disiplin berkendara di sekolah telah melekat pada watak atau kebiasaan siswa, maka disiplin berkendara di jalan raya pun juga akan terwujud. Wuryandani, dkk (2014:288) mengatakan bahwa melalui pendidikan karakter, nilai-nilai karakter yang baik akan tertanam di dalam diri individu. Nilai-nilai karakter yang baik akan menuntun seseorang dalam berperilaku sehari-hari. Pernyataan tersebut juga selaras dengan pendapat Wibowo (2012:36) yang mengatakan bahwa dengan adanya penanaman nilai-nilai luhur kepada peserta didik, maka ia akan memiliki karakter luhur dan menerapkan dalam kehidupannya, baik dalam lingkungan keluarga, lingkungan masyarakat maupun dalam kehidupan berbangsa dan bernegara.

Berdasarkan paparan latar belakang masalah di atas, penulis tertarik untuk meneliti dan mengungkap pembinaan karakter disiplin berkendara di SMP Negeri 9 Yogyakarta. Alasan kuat penulis melakukan penelitian di SMP Negeri 9 Yogyakarta yaitu karena adanya komitmen sekolah dalam melakukan pembinaan karakter disiplin bekendara pada siswa. Komitmen tersebut diwujudkan dalam bentuk pengintegrasian pendidikan disiplin berkendara pada pembelajaran PKn dan pembiasaan untuk menerapkan budaya disiplin berkendara.

Pembinaan karakter disiplin berkendara di SMP Negeri 9 Yogyakarta mempunyai keunggulan karena mampu meminimalisasi pelanggaran tata disiplin berkendara di sekolah. Hal ini ditunjukkan dengan semakin berkurangnya pelanggaran tata disiplin berkendara di sekolah setelah adanya kolaborasi pengintegrasian pendidikan disiplin berkendara pada pembelajaran PKn dan pembiasaan untuk menerapkan budaya disiplin berkendara di sekolah. Bahkan setahun terakhir, hanya ada satu siswa yang melanggar tata disiplin berkendara di SMP Negeri 9 Yogyakarta. Dampak positif ini diharapkan akan mempengaruhi persoalan pelanggaran lalu lintas yang sering dilakukan siswa. Karena proses pembinaan karakter yang baik kepada siswa akan mempengaruhi perilaku siswa dan kemudian menjadi watak atau kebiasaan dalam kehidupan sehari-hari. Awalnya siswa terbiasa disiplin berkendara di sekolah dengan diterapkannya tata tertib dalam berkendara di dalam lingkungan sekolah. Kemudian, lama-kelamaan siswa akan terbiasa disiplin berkendara di masyarakat dengan diterapkannya undang-undang dalam berkendara di lingkungan masyarakat.

\section{METODE}

Penelitian ini merupakan penelitian deskriptif dengan pendekatan kualitatif. Penelitian ini dilaksanakan di SMP Negeri 9 Yogyakarta. Adapun waktu penelitian ini dimulai pada April 2017 sampai April 2018, yang dimulai dari tahap perencaan (pembuatan proposal, seminar instrumen, ijin penelitian, pengumpulan data, analisis data sampai pada penyusunan laporan penelitian. Pemilihan subjek dalam penelitian ini menggunakan teknik purposive. Adapun subjek penelitian ini yaitu guru PKn dan 
kepala sekolah di SMP Negeri 9 Yogyakarta.

Peneliti melakukan wawancara mendalam (in dept-interview) kepada Ibu Sulastri selaku guru PKn SMP Negeri 9 Yogyakarta dan Bapak Arief Wicaksono, M.Pd. selaku kepala sekolah. Peneliti melakukan observasi partisipatif dengan cara mengamati pelaksanaan pembelajaran dalam proses pengintegrasian pendidikan disiplin berkendara pada pembelajaran PKn kelas VII, yaitu pembelajaran norma hukum. Selain itu, peneliti juga melakukan observasi partisipatif dengan cara mengamati sosialisasi tata tertib dan penegakan tata tertib dalam proses penerapan budaya disiplin berkendara di sekolah. Dokumentasi yang digunakan peneliti sebagai sumber data yaitu dokumentasi yang berkaitan dengan pengintegrasian pendidikan disiplin berkendara pada pembelajaran PKn kelas VII dan dokumentasi yang berkaitan dengan penerapan budaya disiplin berkendara di sekolah. Adapun dokumentasi yang berkaitan dengan pengintegrasian pendidikan disiplin berkendara pada pembelajaran PKn kelas VII berupa silabus PKn kelas VII, RPP PKn kelas VII, catatan agenda kelas VII, dan data-data lain yang mendukung penelitian. Sementara, dokumentasi yang berkaitan dengan penerapan budaya disiplin berkendara di sekolah berupa buku panduan pendidikan yang, tata tertib peserta didik, dan data-data lain yang mendukung penelitian.

Data yang terkumpul kemudian diolah dan dianalisis untuk mendapatkan hasil sesuai yang direncanakan. Dalam penelitian ini, peneliti menggunakan analisis data kualitatif dengan model Miles \& Huberman (1994). Langkah-langkah analisis model tersebut meliputi pengumpulan data, reduksi data, penyajian data, dan penarikan kesimpulan.

\section{HASIL DAN PEMBAHASAN}

Proses Pengintegrasian Pendidikan Disiplin Berkendara pada Pembelajaran PKn

\section{Tahap Perencanaan Pembelajaran}

Pendidikan disiplin berkendara di SMP Negeri 9 Yogyakarta diintegrasikan ke dalam pembelajaran PKn kelas VII pada kompetensi dasar memahami norma-norma yang berlaku dalam kehidupan bermasyarakat, berbangsa, dan bernegara. Guru PKn SMP Negeri 9 Yogyakarta mengintegrasikan pendidikan disiplin berkendara pada pembelajaran norma hukum. Kawuryan (2007:52) berpendapat bahwa pendidikan hukum sudah seharusnya diarahkan pada dua hal pokok yakni pembelajaran materi hukum dan penegakan hukum. Pembelajaran pokok pertama bertujuan untuk membekali siswa dengan sejumlah pengetahuan tentang norma-norma hukum yang berpengaruh terhadap kehidupannya sehingga tumbuh kesadaran hukum pada dirinya, yakni kesadaran yang pada gilirannya membuatnya mampu menunjukkan kepatuhan secara sukarela dan bersikap menghormati norma-norma hukum yang berlaku. Pembelajaran pokok yang kedua, yang tidak dapat dipisahkan dari pokok pertama, bertujuan membekali siswa dengan mekanisme, kelembagaan, dan sistem peradilan dalam menegakkan norma-norma hukum. Dalam hal ini, pendidikan disiplin berkendara diarahkan pada pembelajaran materi hukum, yaitu pembelajaran norma hukum yang terdapat pada jenjang kelas VII.

Dengan adanya pengintegrasian pendidikan disiplin berkendara pada pembelajaran norma hukum, siswa secara tidak langsung dibekali sejumlah pengetahuan tentang norma-norma hukum dalam berkendara sehingga diharapkan akan tumbuh kesadaran hukum berkendara pada dirinya yang gilirannya akan membuatnya 
mampu menunjukkan kepatuhan dalam berkendara. Pernyataan tersebut selaras dengan pendapat Wuryandani, dkk (2014: 288) yang mengatakan bahwa penanaman nilai-nilai karakter yang baik akan menuntun seseorang dalam berperilaku seharihari. Selanjutnya, Cholisin (2010:8) mengatakan bahwa pembentukan karakter diarahkan antara lain pada terbentuknya karakter religius, cerdas, jujur, tangguh, demokratis, peduli berpikir kritis, kreatif dan inovatif, kepatuhan terhadap norma-norma sosial yang berlaku dalam kehidupan berbangsa dan bernegara, mandiri, dan percaya diri. Dalam hal ini pembentukan karakter diarahkan pada terbentuknya karakter kepatuhan terhadap norma-norma.

\section{Tahap Pelaksanaan Pembelajaran}

Pendidikan disiplin berkendara yang diintegrasikan pada pembelajaran PKn di SMP Negeri 9 Yogyakarta dilaksanakan guna mencapai kompetensi norma hukum. Pendidikan disiplin berkendara yang diintegrasikan ke dalam materi pembelajaran PKn tentang norma hukum dilaksanakan melalui kegiatan pembelajaran di dalam kelas dan di luar kelas. Kegiatan pembelajaran di dalam kelas berupa kegiatan pembuatan poster berisi pesan moral peraturan lalu lintas, yang nantinya dibawa oleh guru dan siswa dalam melakukan pembelajaran di luar kelas. Pembelajaran di luar kelas berupa kegiatan pengamatan pelanggaran lalu lintas di jalan raya dan himbauan kepada masyarakat untuk disiplin berkendara.

Kegiatan pembelajaran yang bermuatan pendidikan disiplin berkendara yang telah dilakukan oleh guru PKn SMP Negeri 9 Yogyakarta baik pembelajaran di dalam kelas maupun pembelajaran di luar kelas secara keseluruhan telah mencapai titik maksimal. David Kerr (1999:14) menjelaskan bahwa kegiatan pembelajaran PKn yang telah mencapai titik maksimal tidak hanya menginformasikan, tetapijuga menggunakan informasi tersebut untuk membantu peserta didik untuk memahami dan untuk meningkatkan kapasitasnya untuk berpartisipasi secara aktif. Menurut Kerr, pendekatan yang sesuai, yaitu dengan mentransformasikan pembelajaran didaktik ke interaktif, baik di dalam maupun di luar ruang kelas yang dapat dilakukan melalui pekerjaan proyek, pembelajaran independen/mandiri, dan pengalaman partisipatif. Berpedoman pada kerangka teori David Kerr tersebut, dapat disimpulkan bahwa kegiatan pembelajaran PKn yang bermuatan pendidikan disiplin berkendara di SMP Negeri 9 Yogyakarta telah mencapai titik maksimal. Dikatakan maksimal karena guru PKn tidak hanya menginformasikan materi tentang norma hukum (dalam hal ini hukum lalu lintas) saja, tetapi juga membantu siswa untuk memahami adanya permasalahan hukum (dalam hal ini permasalahan pelanggaran lalu lintas) yang masih kerap terjadi di masyarakat dan berusaha meningkatkan kapasitas siswa untuk berpartisipasi aktif dengan cara mengajak/menghimbau masyarakat untuk disiplin berkendara.

\section{Tahap Penilaian Pembelajaran}

Penilaian pembelajaran PKn yang bermuatan pendidikan disiplin berkendara di SMP Negeri 9 Yogyakarta menggunakan penilaian autentik dengan menilai kompetensi pada aspek pengetahuan, keterampilan, dan sikap. Penilaian aspek pengetahuan dilakukan guru PKn SMP Negeri 9 Yogyakarta pada pembelajaran di luar kelas, yaitu dengan menilai laporan hasil pengamatan pelanggaran lalu lintas yang dilakukan siswa. Penilaian aspek keterampilan dilakukan guru PKn SMP Negeri 9 Yogyakarta pada pembelajaran di dalam kelas yaitu dengan menilai kegiatan siswa dalam 
membuat poster. Penilaian aspek sikap dilakukan guru PKn SMP Negeri 9 Yogyakarta pada pembelajaran di luar kelas, yaitu dengan menilai kesadaran siswa dalam kegiatan partisipasi untuk mengajak/menghimbau masyarakat disiplin berkendara.

Dari keseluruhan penilaian pembelajaran yang telah dilakukan guru PKn SMP Negeri 9 Yogyakarta, dapat disimpulkan bahwa penilaian pembelajaran PKn yang bermuatan pendidikan disiplin berkendara telah mengikutsertakan semua aspek baik aspek pengetahuan atau kognitif, aspek keterampilan atau psikomotor, dan aspek sikap atau afektif. Selain itu, keseluruhan penilaian pembelajaran yang bermuatan pendidikan disiplin berkendara menggunakan teknik nontes. Ngalimun (2018:204) menjelaskan bahwa teknik nontes terdiri atas penilaian pengamatan atau observasi, penilaian penugasan, penilaian produk, dan penilaian portofolio. Penilaian pembelajaran yang bermuatan pendidikan disiplin berkendara menggunakan teknik nontes berupa penilaian pengamatan, penilaian penugasan, dan penilaian produk. Sementara, penilaian hasil pembelajaran $\mathrm{PKn}$ yang bermuatan pendidikan disiplin berkendara di SMP Negeri 9 Yogyakarta dilakukan melalui kegiatan remedial bagi siswa yang belum tuntas/belum mencapai nilai KKM (75). Kegiatan remedial dilakukan dengan mengulang materi yang belum dikuasai oleh siswa, khusus untuk aspek sikap dilakukan pembinaan secara holistis yang melibatkan guru BK dan orang tua.

\section{Proses Pembiasaan untuk Melakukan Pe- nerapan Budaya Disiplin Berkendara di Sekolah}

\section{Tahap Penyusunan Tata Tertib}

Tata tertib berkendara di SMP Negeri 9 Yogyakarta dimasukkan pada tata tertib peserta didik. Tata tertib peserta didik yang diatur dalam Keputusan Kepala SMP Negeri 9 Yogyakarta Nomor: 188/003 Tahun 2017 mengatur kehidupan peserta didik selama di sekolah untuk mencapai perilaku disiplin salah satunya mencapai perilaku disiplin siswa dalam berkendara di sekolah. Adanya Keputusan Kepala SMP Negeri 9 Yogyakarta, menunjukkan bahwa SMP Negeri 9 Yogyakarta mempunyai aturan yang jelas tentang tata tertib peserta didik salah satunya tata tertib berkendara di sekolah. Gottfredson, et al. (2005:412) mengatakan bahwa adanya kesepakatan/aturan yang jelas dalam sekolah mempengaruhi perilaku siswa yang positif yaitu siswa menjadi kurang nakal. Berpedoman pada pendapat Gottfredson, et al. tersebut, tata tertib berkendara di sekolah yang diatur dalam Keputusan Kepala SMP Negeri 9 Yogyakarta Nomor: 188/003 sekiranya akan efektif untuk mencapai perilaku disiplin berkendara di sekolah. Namun demikian, sangat disayangkan karena di SMP Negeri 9 Yogyakarta masih belum ada tata tertib yang mengatur tentang kewajiban anak memakai helm ketika diantar orang tuanya menggunakan sepeda motor ke sekolah. Oleh karena itu, sejauh ini belum ada tindak lanjut untuk memberikan sanksi terkait anak yang tidak memakai helm ketika diantar orang tuanya menggunakan sepeda motor.

Jika dilihat tata tertib berkendara di SMP Negeri 9 Yogyakarta yang meliputi norma-norma berkendara, larangan-larangan berkendara, dan pedoman penilaian untuk penerapan sanksi atas pelanggaran tata tertib berkendara dan lainnya dapat disimpulkan bahwa SMP Negeri 9 Yogyakarta telah berupaya untuk mewujudkan pembinaan karakter melalui penerapan budaya disiplin berkendara. Marzuki, dkk (2011: 52-53) menjelaskan bahwa dalam mewujudkan pembinaan karakter di sekolah, 
diperlukan program-program sekolah yang secara tegas dan rinci mendukung terwujudnya karakter atau akhlak mulia tersebut. Program-program ini dirancang dalam rangka pengembangan atau pembiasaan siswa sehari-hari baik dalam pengamalan ajaran-ajaran agama maupun nilai-nilai moral dan etika universal yang dituangkan dalam peraturan sekolah. Selain itu, sekolah juga harus memaksimalkan fungsi pendidikan yang tidak hanya mentransfer norma kepada siswa, tetapi harus sampai pada pengamalan ajaran yang baik sehingga pada akhirnya akan terwujud pembinaan karakternya. Berdasarkan hal tersebut, dapat disimpulkan bahwa SMP Negeri 9 Yogyakarta telah berusaha mewujudkan pembinaan karakter disiplin berkendara melalui pembiasaan siswa dalam pengamalan tata tertib berkendara yang dituangkan secara eksplisit dalam tata tertib peserta didik. Pembiasaan dilakukan melalui penerapan budaya disiplin berkendara di sekolah yang memuat tata tertib peserta didik yang diatur dalam Keputusan Kepala SMP Negeri 9 Yogyakarta Nomor: 188/003 Tahun 2017.

\section{Tahap Sosialisasi Tata Tertib}

Tata tertib yang telah disusun hendaknya disosialisasikan secara berkelanjutan, tujuannya yaitu agar semua pihak memahami dengan baik isi tata tertib yang telah disusun. Di SMP Negeri 9 Yogyakarta, tata tertib berkendara di sekolah juga disosialisasikan secara berkala dan berkelanjutan kepada seluruh warga sekolah terutama siswa dan orang tua siswa. Sekolah menyosialisasikan tata tertib berkendara di sekolah dengan cara memberikan tata tertib peserta didik yang telah dibuat dalam bentuk tertulis. Tata tertib tersebut dimasukkan ke dalam buku panduan pendidikan SMP Negeri 9 Yogyakarta. Buku pandu- an pendidikan SMP Negeri 9 Yogyakarta tersebut tidak hanya memuat tata tertib saja, tetapi juga memuat catatan pelanggaran tata tertib. Hal ini sesuai dengan pendapat Daryanto (2015:84-90) yang menyatakan bahwa sosialisasi untuk para orang tua siswa dapat dilakukan dengan cara mengirimkan tata tertib yang telah dibuat dalam bentuk tertulis kepada mereka. Dalam hal ini, sosialisasi kepada orang tua siswa dilakukan dengan memberikan satu buku panduan melalui anak, jadi orang tua siswa bisa memahami tata tertib tersebut. Selain itu, dengan adanya buku panduan tersebut, orang tua siswa bisa memantau perkembangan anak selama di sekolah melalui catatan pelanggaran tata tertib. Hal tersebut sesuai dengan pendapat Taylor, et al. (2004:163) yang mengatakan bahwa sosialisasi akademik kepada orang tua dapat mempengaruhi perkembangan anak sekolah. Oleh karena itu, hendaknya sosialisasi dapat dilakukan secara berkala dan berkelanjutan. Selanjutnya sosialisasi tata tertib berkendara di SMP Negeri 9 Yogyakarta yang ditujukan kepada orang tua/wali siswa dilakukan melalui "Kajian Ahad Pagi" yang dilakukan setiap semester.

Tata tertib berkendara di SMP Negeri 9 Yogyakarta juga disosialisasikan kepada siswa. Sosialisasi tata tertib berkendara telah disosialisasikan sejak siswa mengikuti kegiatan PLS (MOS). Selain itu, sosialisasi juga dilaksanakan pada saat upacara bendera. Pada waktu tertentu, sekolah mengundang pihak luar sesuai jabatannya untuk menjadi Pembina Upacara. Untuk pembinaan etika berlalu lintas, Kapolsek dan Koramil Kotagede merupakan narasumber yang paling sering diundang ke sekolah. Sekurang-kurangnya 2 kali dalam setahun juga, SMP Negeri 9 Yogyakarta mendapat tamu kehormatan dari Dikyasa Polresta Yogyakarta untuk membina upacara dalam 
rangka menyampaikan pesan-pesan tentang ketertiban dalam berkendara.

\section{Tahap Penegakan Tata Tertib}

Tata tertib yang baik adalah tata tertib yang ditegakkan secara konsekuen. Agar tata tertib di sekolah dapat berarti bagi pengembangan budaya sekolah, tata tertib tersebut harus dilaksanakan atau ditegakkan. Penegakan tata tertib berkendara di SMP Negeri 9 Yogyakarta dilaksanakan melalui kegiatan sidak. Kegiatan sidak dilakukan secara berkala pada periode tertentu. Dalam hal ini, pihak sekolah bekerjasama dengan pihak kepolisian melakukan razia atau pemeriksaan terhadap peserta didik yang diduga mengendarai sendiri kendaraan bermotor ke sekolah, pada tempat penitipan kendaraan bermotor atau rumahrumah penduduk di sekitar sekolah. Jika ada siswa yang melanggar tata tertib berkendara di sekolah, maka siswa tersebut akan diberikan sanksi. Penjatuhan sanksi dilakukan secara bertahap, mulai dari peringatan, teguran, skorsing sampai dikeluarkan. Selain diberikan peringatan dan teguran, siswa akan disuruh membuat surat pernyataan yang isinya berjanji untuk tidak melanggar tata tertib sekolah lagi. Hal tersebut selaras dengan pendapat Daryanto (2015:84-90) yang menyarankan agar penjatuhan sanksi dilakukan secara bertahap kepada semua unsur yang ada di sekolah mulai dari peringatan, teguran, percobaan, penundaan, demosi, dan PHK atau dikeluarkan sampai masalah itu terpecahkan atau dihilangkan. Selain itu, Hernawati (2017:15) juga membuktikan bahwa ada pengaruh antara penerapan sanksi yang dilakukan secara bertahap terhadap kedisiplinan siswa. Berpedoman dari beberapa pendapat di atas, maka sebaiknya penerapan sanksi dilakukan secara bertahap sehingga mampu mempengaruhi kedisiplin- an siswa dalam hal ini kedisiplinan siswa dalam berkendara di sekolah.

\section{PENUTUP}

Pembinaan karakter disiplin berkendara di SMP Negeri 9 Yogyakarta secara eksplisit diintegrasikan pada pembelajaran PKn melalui pembelajaran norma hukum. Selain itu, komitmen pembinaan karakter disiplin berkendara di sekolah tersebut dikolaborasikan dengan adanya pembiasaan untuk menerapkan budaya disiplin berkendara di sekolah melalui penegakan tata tertib peserta didik. Dengan berbagai upaya yang dilakukan pembinaan karakter disiplin di kalangan para siswa di SMP Negeri 9 Yogyakarta melalui pembelajaran Pendidikan Kewarganetaan ini cukup berhasil.

Disipilin berlalu lintas atau berkendara hendaknya dilakukan sejak dini, seperti ketika anak sedang belajar di tingkat SMP agar kesadaran berlalu lintas yang benar tertanam sejak dini. Banyaknya pelanggaran lalu lintas yang dilakukan oleh anak-anak yang masih duduk di bangku SMP atau SMA bisa jadi karena belum dilakukannya sosialisasi kepada mereka tentang aturan perundangan yang terkait dengan masalah lalu lintas. Oleh karena itu, apa yang dilakukan oleh SMP Negeri 9 Yogyakarta, khususnya melalui pembelajaran PKn yang mengintegrasikan disiplin berkendara patut diapresiasi dan dapat diikuti oleh guru-guru lain di sekolah-sekolah lain di wilayah nusantara.

\section{UCAPAN TERIMA KASIH}

Dengan dimuatnya artikel hasil penelitian ini di Jurnal Pendidikan Karakter, penulis mengucapakan terima kasih kepada berbagai pihak yang telah membantu proses penelitian penelitian hingga terselesaikannya tulisan ini. Ucapan terima kasih terutama disampaikan kepada Kepala 
Sekolah SMP N 9 Yogyakarta, Guru PKn SMP N 9 Yogyakarta, dan Keluarga Besar SMP N 9 Yogyakarta yang telah memberikan informasi dan data yang dibutuhkan peneliti. Ucapan terima kasih juga penulis sampaikan kepada ketua dan anggota Dewan Redaksi Jurnal Pendidikan Karakter Universitas Negeri Yogyakarta yang telah bersedia mereviu dan menyetujui tulisan ini, sehingga akhirnya diterima dan diterbitkan.

\section{DAFTAR PUSTAKA}

Ali, Z. (2007). Sosiologi hukum. Jakarta: Sinar Grafika.

Cholisin. (2010). Membentuk karakter dalam pendidikan hukum warga negara. Makalah, disampaikan dalam seminar nasional "Peran civil society terhadap pendidikan hukum dan penegakan hukum di Indonesia". Diselenggarakan oleh Anggota Himnas PKn Unviversitas Negeri Malang dan Himpunan Mahasiswa Jurusan Hukum dan Kewarganegaraan Universitas Negeri Malang. http://staffnew.uny.ac.id/upload/131474282/p enelitian/membentuk+karakter+dala $\mathrm{m}+$ pendidikan+hukum+warga+nega ra.pdf.

Daryanto. (2015). Pengelolaan budaya dan iklim sekolah. Yogyakarta: Gava Media.

Dewi, P.D. (2017). Angka kecelakaan lalu lintas Indonesia termasuk tinggi di ASEAN. Antara. 15 November 2017. https://antaranews.com/berita/ 6649 79/angka-kecelakaan-lalu-lintas-indonesia-termasuk-tinggi-di-asean.

Durkin, M.S. (1999). Epidemology and prevention of traffic injuries to urban children and adolescents. Pediatrics. 103(6). 1-8. DOI: http://dx.doi.org/10.1542/peds.103.6.e74.

Gottfredson, G.D. et al. (2005). School climate predictators of school disorder: results from a national study of delinquency preventionin schools. Journal of Research in Crime and Delinquency. 42(4), 412-444. DOI: http://journals.sagepub.com/doi/abs/10.11 77/0022427804271931.

Hernawati, N. (2017). Pengaruh penerapan sanksi berjenjang terhadap kedisiplinan siswa di SDN Mekarwangi 1 Kecamatan Cihurip Kabupaten Garut. Jurnal Pendidikan UNIGA, 2(1), 10-16. https://journal.uniga.ac.id/index.php/JP/article/view/12.

Kawuryan, S.P. (2007). Peran mata pelajaran PKn SD sebagai wahana pendidikan hukum bagi anak. Majalah Ilmiah Pembelajaran, 3(1), 49-59. URL: https://journal.uny.ac.id/index.php/mip /article/viewFile/6405/5532.

Kerr, David. (1999). Citizenship education in the curriculum: An international review. The School Field, 10(3/4), 5-32. URL: file:// / C:/Users/UNY/Downloads/citizenshipeducationinthecurri culum.pdf.

Kuncorowati, P.W. (2009). Menurunnya tingkat kesadaran hukum masyarakat di Indonesia. Jurnal Civics, 6(1), 60-75. DOI: 10.21831/civics.v6i1.5678.

Maftuh, B. \& Sapriya. (2005). Pembelajaran Pendidikan Kewarganegaraan melalui pemetaan konsep. Jurnal Civicus, 1(5), 319-321. 
Marzuki, dkk. (2011). Pembinaan karakter siswa berbasis pendidikan agama. Jurnal Kependidikan, 41(1), 45-53. DOI: https://doi.org/10.21831/jk.v4 1i1.1919.

Miles, M.B. \& Huberman, A.M. (1994). Qualitative data analysis: An expanded sourcebook. Oaks, London, Ney Delhi: Sage Publication.

Movanita, A.N.K. (2017). Wakapolri sebut disiplin harus dibangun untuk kurangi kecelakaan. Kompas. 30 Juli 2017. http://nasional.kompas.com/read/2 017/07/30/10381631/wakapolri-sebut-disiplin-harus-dibangun-untukkurangi-kecelakaan.

Ngalimun. (2018). Evaluasi dan penilaian pembelajaran. Yogyakarta: Parama Ilmu.

Purnama, A. (2017). Pelajar sering terlibat kecelakaan. Tribun Jogja. 22 Februari 2017. http://jogja.tribunnews.com/2017/02/22/ pelajar-sering-terlibatkecelakaan.

Ravel, S. (2017a). Akibat pembiaran, angka kecelakaan tumbuh subur. Kompas. 9 Maret 2017. http://otomotif.kompas.com/read/2017/03/09/072200715/akibat.pembiaran.angka.kecelaka an.tumbuh.subur.
Ravel, S. (2017b). Jurus baru polisi tekan kecelakaan lalu lintas. Kompas. 10 Januari 2017. http:/ / otomotif.kompas.com/read/2017/01/10/171919515/jurus.baru.polisi.tekan.kecelakaan.lal u.lintas.

Rostanti, Q. (2017). Jumlah kecelakaan di Indonesia empat tahun terakhir. Republika. 02 Mei 2017. http://m.republika.ci.id/berita/nasional/umum/1 7/05/02/opaywe326-jumlah-kecelakaan-di-indonesia-empat-tahun-terakhir.

Sunarso, dkk. (2008). Pendidikan kewarganegaraan. Yogyakarta: UNY Press.

Taylor, L.C. et al. (2004). Academic socialization: understanding parental influences on children's school-relted development in the early years. Review of General Psychology, 8(3), 163178. DOI: https://doi.org/10.1037/1089-2680.8.3.163.

Wibowo, A. (2012). Pendidikan karakter: Strategi membangun karakter bangsa berperadaban. Yogyakarta: Pustaka Pelajar.

Wuryandani, W. dkk. (2014). Pendidikan karakter disiplin di sekolah dasar. Cakrawala Pendidikan, 33(2), 286-295. DOI: https:// doi.org/10.21831/cp.v2 i2.2168. 